\title{
An Evaluation of Rental Housing Affordability by Staff of Tertiary Institutions in Owerri, Imo State, Nigeria
}

\author{
Jovita N. Nnametu1, Fidelis I. Emoh² \\ ${ }^{1}$ Department of Quantity Surveying, Federal University of Technology, Owerri, Nigeria \\ ${ }^{2}$ Department of Architecture and Planning, University of Botswana, Gaborone, Botswana \\ Email: jnnametu@yahoo.co.uk, fidelis.emoh@mopipi.ub.bw
}

How to cite this paper: Nnametu, J.N., \& Emoh, F.I. (2020). An Evaluation of Rental Housing Affordability by Staff of Tertiary Institutions in Owerri, Imo State, Nigeria. Current Urban Studies, 8, 1-23. https://doi.org/10.4236/cus.2020.81001

Received: November 25, 2019

Accepted: January 6, 2020

Published: January 9, 2020

Copyright ( 2020 by author(s) and Scientific Research Publishing Inc. This work is licensed under the Creative Commons Attribution International License (CC BY 4.0).

http://creativecommons.org/licenses/by/4.0/ (c) (i) Open Access

\begin{abstract}
There has been a serious threat to rental accommodation in the urban areas especially to certain grade of workers in the tertiary institutions, whose income in most cases are based on their salaries. The ever increasing cost of rental accommodation has nevertheless forced this group of workers to spend greater part of their income in search of adequate accommodation. The paper is an evaluation of adequate rental housing affordability by workers in relation to their income levels and other household needs, using the staff of tertiary institutions in Owerri, Imo State of Nigeria. The research also tried to find out the variables that affect the choice of rents and thus rate them according to their level of significance. Data were drawn from 01-09 salary grade levels comprising of both academic and non-academic staff of the five tertiary institutions in Owerri. 250 samples were selected using stratified random sampling techniques, same number of questionnaires was distributed, and 210 of the questionnaires were returned. Out of that, 191 questionnaires were considered valid, while the remaining was invalid. Tables and Percentages were used to analyze most of the data, while Statistical Program for Social Sciences (SPSS) software package was used to run a multiple regression. In the analysis, actual rent was the dependent variable while income, family size and other household expenditure were the independent variables. As a result the following estimated equation was developed Y (Affordable rent $)=75.527+(0.05037$ income $)+(8.578$ family size $)+(0.01254$ other household expenditure). The study revealed that three variables constitute $41 \%$ of the total variables that influence adequate rental affordability. The result of combined variables shows that $f_{\text {cal }}=43.377$ as against $f_{\text {tab }}$ of 1.20 which explains that the three variable are important as determinants. The result of $t_{\text {cal }}$ (testing the significance of the individual variables) reveals that income
\end{abstract}


ranks the highest determinant; family size becomes the next while other expenditures were not so significant. The paper recommended an introduction of staff housing scheme especially for the lower income group, to alleviate the cost of housing and transportation.

\section{Keywords}

Rental Housing Affordability, Tertiary Institutions, Evaluation, Owerri, Nigeria

\section{Introduction}

Housing is one of man's basic necessities for physical, economical and mental development. It has been universally acclaimed as the second most essential human need after food. As a basic need of mankind, housing exhibits the attribute of being the most durable item that impacts positively on man's productivity. When a worker lacks adequate accommodation, his productivity, health and general well-being could be affected. Olayinwola, Adeleye and Ogunshakin (2005) observed that it also stipulates social stability, the work efficiency and development of an individual. The provision of housing accommodation encompasses social, environmental necessity, political and economic approaches necessary to support peace and stable development in the world. Housing goes beyond a mere shelter to embrace social services and utilities, which merge together to make a community or neighborhood a livable place. The United Nation Organization (UNO) defines housing as "residential physical structures that mankind uses as a shelter, including all the necessary services, facilities, equipment and devices needed or desired for physical and mental well-being of a man". All these tend to elucidate that housing could be a good measure in equating a person's living standard, as well as his physical and mental stability. Therefore any housing unit that has the ability to satisfy the above concept is regarded as adequate. Unfortunately, this essential commodity is not readily available for the majority of people to access or afford due to many contending issues that are tied up to its provision.

Globally, the problem of housing affordability is usually complex and diverse as it is directly related to household income, since it is the ability to acquire housing from household income without sacrificing any of the other essential needs of the household. In order to meet the enormous housing challenges particularly in developing countries including Nigeria, the international community at Istanbul, Turkey in 1996 established the Habitat Agenda on housing to provide adequate shelter for all, achieve sustainable human settlements as well as the recognition of the primary responsibility for the Agenda. The increase in population, especially in the urban areas, had always resulted in inadequate housing provision. These problems are more pronounced in the developing Nations due 
to rural-urban drift. Nigeria as one of the developing nations is not devoid of this problem that has continued to pose threats to our national development. In line with this, the Federal Government had at various stages of developmental vision made provisions for housing for all which are yet to be realised. Formulations of numerous national development plans, housing programs and national housing policies attest to government efforts toward solving the housing problems.

Affordability in all intents and purposes is the ability to pay for adequate housing. According to Onyike (2007), it looks at whether the form (design), technology (functions and amenities) and cost of housing are compatible with the income flow of prospective consumers. Housing is one of the numerous household needs that compete for the fixed household incomes for the majority of residents of Owerri who are salary earners. The cost of affording adequate housing in the city tends to rip-off the major part of the income to the disadvantage of other competing needs. This can be attributed to scarcity of housing accommodation. The existing housing problem cannot solely be attributed to rural-urban drift; rather poor effective implementation of housing programs of government is also a very significant factor. With the population growth and urbanization, the demands for housing in the city continue to increase while supplies are more or less static. The lingering problem of housing demand outburst vis-à-vis supply has propelled the increase in property values beyond the affordability capacity of many households especially the fixed income earners in Owerri.

The situation has continued to encourage the incidence of non-payment or prompt payment of house rent on expiration of tenancy. More to it is the development of slum and squalor or squatter settlement within the city. Residents while in search of this basic need (shelter) resort to living in accommodation that poses threat to human health and safety.

As an administrative city, the predominant population of Owerri is workers made up of public servants in the federal and state ministries, parastatals, institutions and the organized private sector. The incomes of these workers are more or less fixed and thus being competed for by housing together with other household needs. Relating these household incomes to cost of housing in Owerri, only a negligible number of the workers can afford the least of what could be termed adequate housing even if their entire salary should be devoted to housing alone. Hence a threat to housing affordability for the low- and medium-income groups in the city.

The continuous rise in property values is the aftermath of housing shortage which can be attributed to numerous challenges. Most layouts in Owerri are reserved for a stipulated type of development and this regulation limits the number of residence. Aladimma, Trans-Egbu, Pre-Fab, part of World bank Housing Estates are mostly bungalows that accommodate fewer households as opposed to Ikenegbu, Akwakuma, Orji and other layouts that have blocks of flats. Works 
Layout, New Owerri layout and Egbeda Federal housing are also designated for duplex and owner occupier, which invariably limits the accommodation to the high-income earners. These layouts were built up in accordance with the existing policies of the State. Orji, Amakohia and the greater part of the central business district have scattered housing development as a result of the original habitants who still retain their ancestral home, thus less accommodation for the residents.

The clustered nature of development in Owerri has created a hitch to spatial expansion of housing towards the suburbs. The absence of government intervention in the provision of access roads and other amenities within the adjoining suburbs has led to the slow or sluggish development of housing within the area, thereby contributing to scarcity of accommodation for Owerri residents especially the workers in the Public Service. On the other hand, the profit maximization objectives of the major actors in the housing industry like developers and the funding institutions tend to conflict with the affordability of housing to majority of the public servants. Access to National Housing Fund (NHF) scheme and other forms of assistance from either the government or financial institutions to meet the cost of housing facility has been an illusion (a mirage).

This scenario has occasioned a continual increase in housing stress on workers in Owerri. When the provision for housing affects the ability of the household to meet other essential needs, the household is said to be suffering from housing stress (Shire, 2002; Onyike, 2007).

The thrust of the paper is, therefore, an evaluation of adequate rental housing affordability by workers in relation to their income levels and other household needs, using the staff of tertiary institutions in Owerri, Imo State of Nigeria. The research also tried to find out the variables that affect the choice of rents and thus rate them according to their level of significance.

\section{The Study Area}

Owerri was made a capital on creation of Imo State in 1976 under the Military Head of State, General Murtala Mohammed. The capital city is located on a longitude of $5.485^{\circ} \mathrm{N}$ and latitude of $7.035^{\circ} \mathrm{E}$ (http://wikepedia.org/wikki/Owerri, 2009). It has natural boundaries with the Otamiri River to the east and the Nworie River to the south. It is also at the intersection bounded by routes to various area such as Port Harcourt, Aba, Okigwe, Orlu, Umuahia and Onitsha respectively (http://www.britannica.com/). Although there are no pronounced hills within Owerri, but it has such feature as one proceeds into the city through the Okigwe axis. Hence Owerri is characterized with flat table land which explains the flooding tendencies whenever there is heavy downpour. The city developed area covers a geographical landmass of $104 \mathrm{~km}^{2}$ (40.2 sq miles), set in the heart of the Igboland with explains the State's slogan as the Eastern heartland.

According to National Population (NP, 2006), the estimated populations of the three local government areas that make up Owerri capital territory are as follows: 
Owerri North 175,395;

Owerri West 99,265;

Owerri Municipal 127,213;

Owerri capital territory 401,873;

Federal Republic of Nigeria Official Gazette No 24 Vol.94 15 May 2007 Lagos, Nigeria.

Owerri has the highest tertiary institutions in the state. Notable among these are:

1) Imo State University, Owerri;

2) Federal University of Technology Owerri;

3) AlvanIkoku Federal College of Education, Owerri;

4) Seat of Wisdom Seminary Owerri;

5) Federal Polytechnic Nekede, Owerri;

6) African Institute of Science and Technology (AIST CCE Owerri);

7) Federal College of Land Resources Oforola.

Owerri as an urban city is characterized by higher levels of population density, higher population growth rates, and higher levels of immigration, higher costs and value of developed and undeveloped properties, also higher levels of income and employment disparities than other developed towns in Imo State. The fact still remains that housing problems in the urban centres are generally more severe and profound than rural housing problems both in their intensity and complexity due to rural-urban drift.

\section{Housing Affordability}

Affordability in its literary sense is someone's ability to meet the financial obligations in terms of paying for adequate housing. Adequate housing possesses the essential physical, environmental and social attributes that satisfy minimum standard of living. Stone (1993) declares also that affordability is the ability of household to pay the cost of housing without imposing constraints on living costs. Relating housing affordability to other household costs, Freeman, A., Chaplin R. \& Whitehead, C. (1997) were of the view that housing affordability concentrates on the relationship between housing expenditure and household income and defines a (relative or absolute) standard in terms of that income above which housing is regarded as unaffordable. Affordability goes beyond housing alone as it includes the quality of housing which the household is able to afford not necessarily affecting the remaining income in relation to other household needs. Bramley (1990) further specified that "households should be able to occupy housing that meets well established (social housing) norms of adequacy (given household type and size) at a net rent which leaves them enough income to live on without falling below some poverty standard." Thus, an increase or decrease in housing affordability often has a significant impact on a household's budget, with far reaching implications especially if there is a downward shift in affordability (Stone, 1993). 
Housing affordability is not just a mere household or individual issue as it impacts on the general well-being of the national economy. As has been contended by Yates et al. (2007: p. 27) "housing affordability is important not just because of the costs borne by the individual households experiencing high housing costs, but also because it imposes costs on the wider economy and society". The relevance of the knowledge of housing affordability has more reaching effect beyond the personal troubles experienced by individual households. In line with the same view, Gabriel, M. Jacobs, K. Arthurson, K. Burke, T. \& Yates, J. (2005) explained that housing affordability has "implications not just for housing but also for employment, health, labour market, aged care, finance, community sustainability, economic development and urban and regional development".

Housing affordability is ambiguous in meaning as no single definition can really qualify its nature as such different groups struggle to impose their own definition and solution to the problem. Quigley and Raphael (2004: pp. 191-102) attempt to reflect on the ambiguity of housing affordability by relating it to a number of disparate issues as: the distribution of housing prices, the distribution of housing quality, the distribution of income, the ability of households to borrow, public policies affecting housing markets, conditions affecting the supply of new or refurbished housing, and the choices that people make about how much housing to consume relative to other goods. These basic issues relating to housing affordability creates difficulty in the interpretation of the basic facts. The various definitions tend towards the different levels of emphases on some or all of the three aspects of affordability: socially acceptable housing, housing cost and quality of life. The concept of adequacy of shelter and residual income (i.e. remaining income after all personal debts including house rent or mortgage have been paid) are considered the core components of the definition of housing affordability (Ndubueze, 2009).

The relevance of housing affordability stems from the fact that Housing is not only a necessity of life but also has a pervasive impact on all aspects of human existence. Stone (1993) noted that Housing, if it is adequate, provides privacy and security against intrusions, both physical and emotional. Adequate housing continues to be a key factor in determining a family access to economic and educational opportunities, exposure to violence and environmental hazards, and ability to accumulate financial assets.

The importance of housing affordability is that it defines the level of households and determines the entire environment in which they live, at the same instance crucial in determining the living standard of these households. It explains how reduce affordability could force a household down the housing ladder or indeed trap such a household in a poor housing environment indefinitely. The emergence of housing stress is as a result of reduced housing affordability hence Byron Shire (2002) opined that when the provision of housing affects the ability of household to meet other essential needs, the household is said to be suffering 
from housing stress. In most of these cases, the households are usually exposed to all the dangerous and undesirable (physical, health, emotional, mental) substandard overcrowded and dilapidated housing environments. The growing interest in housing affordability discussions is of vital importance due to the ever increasing incidence of housing crises especially within the major cities of the country. It is however significant to note that the current interest in housing affordability cuts across different ideological and intellectual divides. These ideologies which have been transformed into housing reforms can only be workable if efforts could be geared towards minimizing the ever increasing housing affordability problems. However, dealing with issues on housing affordability problems would logically lead to questions of how incomes and housing costs are determined and the underlying tension between them. Thus the inquiry into fundamental systemic stress and tension between the housing market and the labour market inherent in a market economy would expose the innate contradictions of market reforms and advance contentions of their unsuitability as a platform to building an equitable and egalitarian society (Stone, 1993). The relevance of housing affordability cannot be over flogged because it goes beyond on the household cost to affect the wider economy and society. This goes to explain that an increase or decrease in housing affordability often has significant impact on a household's budget, with far reaching implications especially if there is a downward shift in affordability (Stone, 1993; Quigley \& Raphael, 2004). The persistent discussions on housing affordability are to some extent necessitated by the need to prevent and deal with the increasing evidence of housing crises that has been prevalent in the towns especially the major cities in the country.

Housing affordability has no definite method of measurement but can actually be conceived or defined based on the various circumstances of individual and collective household. Depending on the angle in which one desires to measure, it is imperative to observe that no single indicator is accurate in all situations. In line with this contention, Marjorie (1998) opined that policy analysts and scholars often devise housing affordability indices based on a combination of indicators, assumptions and analytical methods. He stress that while assessing housing affordability, researchers need to determine the most appropriate indicator that could match the research motive.

Housing affordability can thus be measured using the following elements, approaches or indicators: Housing Cost Approach, The Non-Housing Cost Approach, Quality Adjusted Approach and Affordability Gap Approach.

The Housing cost Approach examines the extent of housing expenditure on the household income. As the most common measure of housing affordability, it assesses the ratio between what households pay for their housing and what they earn. Ndubueze (2009) opined that a 'rule of thumb' standard of no more than $25 \%$ (or sometimes $30 \%$ and higher) of household monthly income being spent on housing costs is deemed appropriate and affordable. This assertion was developed from the works of Feins and Lane (1981), as he observed that this tradi- 
tion was rooted in common wisdom and experience in America where by the end of the 1930s the notion was generally accepted as a way to describe actual family housing expenses and a standard for the maximum proportion of income that should be devoted to mortgage payments. Bogdon and Can (1997) were of the opinion that if used in conjunction with other affordability measures, the house price-to-income ratio has the potential to provide a useful starting point to examine housing affordability problems. Rent-To-Income Ratio measures the average annual rent of dwelling unit in relation to the average annual household income. This ratio assumes that affordable rental-housing should cost no more than a certain percentage (usually about $25 \%$ - 30\%) of household's monthly income (Ndubueze, 2009). Arguments had been on the appropriate income to use for the analysis based on the wide range of income such as gross income, net income, equivalent income, equivalent-after-tax income; the addition of any housing allowance to rent or to net income; which has erupted to variations in the ratio. The most appropriate approach is for different countries to adopt the most convenient approach in relation to their particular housing subsidy or social housing benefits. This presupposes that household access to adequate housing means that housing expenditures do not take up an undue portion of their income. The issue of "undue portion of income" in various countries may range between 25 to 35 percent of household income (Freeman \& Whitehead, 1995).

Housing affordability has a complex nature which explains that no single approach will be accurate in all situations. Hence the combination of these approaches could provide a better platform in housing affordability research.

Omoniyi (1994) in his work affirms that the measurement of adequate housing involves condition that creates foundation for a healthy, socio-economic and political relationship as against a sub-standard one that can leave a serious negative impact on the individuals or community health and peace. The quality of life is also primarily determined by the availability of adequate and qualitative housing, which must include adequate services such as good road network, available communication network, electricity, water and transporting.

\section{Challenges to Providing Affordable Housing in Nigeria}

Housing Affordability is directly related to income as it is the ability to afford or pay for adequate housing. It looks at whether the form, technology and cost of housing are compatible with the income flow of the prospective consumer of housing (Onyike, 2007). Household income is confronted with a lot of compulsory expenditure as feeding, clothing, housing (rent), transportation, education (school fees) and medical. On deduction of these expenses, the difference then becomes the spendable income through which fund for purchase of housing will be extracted. The onus lies on the possibility of the household income to fund housing development without any consociate funding. The then Governor of Lagos State, Nigeria, Mr. Babatunde Fashola, a Senior Advocate of Nigeria (SAN) confirmed that the bane of housing development in Nigeria is that its 
funding is largely dependent on household income (Kolawole, 2010). This is on the premise that home prices and rents have grown ahead of general inflation that is exerting on all aspects of household expenditure. Making matters worse, Nubi (2008) exclaimed that the composition of homes for sale and rent on the Nigerian property market has been inevitably shifting towards very expensive home. The affordable housing delivery vicious cycle is such that high cost of housing relative to income leads to reduction in demand, which invariably is caused by affordability, leading to reduced investment in housing to match demand. All these result to reduction in supply in housing that lead to high cost.

It is observed that a large percentage of residential housing stock in most urban towns is funded by household income. This contrasts sharply with what obtains elsewhere, especially in the advanced countries where the bulk of funding for housing development is from mortgage institutions. If accessing housing should only be based on household income, then the possibility of affording adequate housing will become an illusion especially to majority of civil servants whose income are at all times swallowed up by their compulsory household expenditure. With the average monthly wage level of N45,000 (USSD 125 dollars), most Nigerians cannot afford average monthly rent level of N30,000 naira (USSD 83 Dollars) for a two-bedroom apartment in the cities

Another major challenge facing housing affordability is the inadequacy in the supply of housing. The rate at which houses are supplied remains a factor of availability of housing input such as land, finance, construction materials, labour and basic infrastructure. Unless there is an adequate supply of housing inputs to aid housing production, it will neither be possible to create a thriving housing market nor provide adequate housing that will be affordable for the teeming population. The Nigeria's Vision 2020 National Technical Working Group on Housing enumerated numerous issues and challenges that affect the housing sector. These anomalies underscore the need for an active and forceful government intervention and involvement in the supply and distribution of housing inputs. The key areas where these interventions are needed include matters relating to land transactions, housing finance, statutory land reform measures, skill and capacity building, access to cheap and affordable building materials and provision of basic infrastructure.

The process of land acquisition in Nigeria under the Land Use Act of 1978 involves series of stages which can be frustrating before possession is taken. The procedure creates opportunity for corruption, and other clandestine activities which at the long run hike the acquisition cost of the land especially for the lower income earner. Often time, the number of application exceeds the available plot for allocation. Land registration is an aspect of administration that facilitates alienation and disposition of land. It is the safe and easy means of recording transactions on land by which security of title is assured in contrast to unregistered conveyance.The difficulty associated with registration of land in Nigeria and the subsequent security to the title has made people to desist from 
doing the proper things. The rigors, incessant imposition of illegal fees coupled with clandestine activities of technocrats culminate to hike land prices and make it unaffordable for the masses.

The high construction cost is also another big challenge to providing affordable housing in Nigeria. Asogwa (2010) asserted that the major challenge they encounter in Enugu State Housing Development Corporation, Nigeria is the high cost of building materials and same has led to ever increasing cost of houses. He affirmed that the attempt by firms to maintain a profitability ratio has translated to cost-cutting measures. The rippling effect of these cost-cutting measures in building materials is degeneration to the use of poor quality of materials that might result to having unsafe structure.

Finance has been the motivating and engineering factor in the construction industry, indeed in all sorts of development. It is a pecuniary resources used in acquisition of goods and services including housing or real estate development. As an activity that has long term duration and at the same time capital intensive in nature, it requires a well-structured financial system. In this regard, financing housing through personal finance recourses only will require slow and tedious accumulation of savings.

\section{Material and Methods}

The research adopted the Survey Method. In order to ensure adequate guide and conformity to the plan of the research, questionnaires, personal interviews and personal observations were adopted to obtain relevant data.

The study area selection was based on multi-stage approach, which has Imo state at the peripheral level and Owerri the main study area. It was selected among other developed towns in Imo state based on the following premise:

1) About $85 \%$ of all tertiary educational institutions (TELs) (Universities, Polytechnics and colleges) both for Federal and state are situated in Owerri.

2) High concentration of housing development both Public and Private owned.

3) Owerri has more defined layouts than other urban areas in Imo State.

Although there are various layouts in Owerri, the research depended on some layouts that had well defined data. These layouts were as follows Low density area-Akanchawa/Concord Axis, Aladimma Estate, Works layout and Egbeada Housing. Middle income-Ikenegbu layout, World Bank Estate, Trans-Egbu layout, parts of Amakohia, Federal housing and Akwakuma and high-density Owerri municipal, Orji, Nekede Old road, parts of Akwakuma.

For proper analysis of housing affordability by public servants in Owerri, the research adopted a uniform property type for a particular category of worker based on their income level. The types of housing developments considered in the study were; Duplex, detached and semi-detached bungalows, block of flats and tenement buildings.

Data of different forms were collected from various sources to validate the 
study. Purposive technique was employed in selecting relevant data for the study. The data were basically from primary and secondary sources.

The population for the study was made up of academic and non-academic staff within income group salary grade levels 01-09, in both Federal and State tertiary institutions in Owerri. A stratified random sampling technique was adopted due to the nature of stratified population in the study. The population size of these workers was estimated to be about 3,000 and using Yamane's formula, a sample of two hundred and fifty was drawn from the five tertiary institutions as cited by Onyike (2009) provides a simplified formula to calculate sample sizes as follows:

$$
n=\frac{N}{1+N(e)^{2}}
$$

where $n=$ sample size;

$N=$ population;

$e=$ level of precision or standard error i.e. 0.05 .

Research instruments used in this work include tables, percentages and statistical tools like multiple regression analysis. These were used to examine the effect of income and other variables on housing affordability.

The formula for multiple regression analysis:

$$
Y=a+b_{1} X_{1}+b_{2} X_{2}+\cdots+b_{n} X_{n}+e
$$

where:

$Y=$ the dependent variable representing affordable rent;

$a=$ a constant (the intercept on the $Y$ axis);

$b=$ the partial regression coefficient representing percentage change in $Y$ resulting from a unit change in income and other variables;

$n=$ number of observations;

$e=$ error term.

Questionnaire was designed to facilitate primary data collection on respondent household size, income, expenditure profile, preferences, rate of adequacy, etc. Staff of the Bursary Departments of the tertiary institutions and Estate Surveyors were interviewed to obtain some key information. A market survey was also conducted to ascertain other relevant issues that were not specified in the questionnaire. The respondents were required to complete questionnaire covering their household size, income, expenditure and to examine the adequacy of their present accommodation in relation to their income and places of work.

Data were analyzed using the statistical package for social sciences (SPSS), while simple percentage was used to analyze the adequacy of housing for the respondents. The computer analysis gave estimates for $\mathrm{a}$ and $\mathrm{b}$ as well as coefficient of determination $\left(R^{2}\right)$ and the $Z$ values for testing $d$ relationship between income or other household variables and housing affordability.

$\mathrm{R}^{2}$ is a statistical measure for showing how adequate the model fits the data. Thus an $\mathrm{R}^{2}$ of $95 \%$ shows that income determines affordability to the tune of 
$95 \%$ which is a good fit.

If $\mathrm{Z}>\mathrm{Z}_{\text {table }}$ (=1.96 @ 0.05 level of significance), it means that income is a major determinant of housing affordability. If however $\mathrm{Z}<\mathrm{Z}_{\text {table, }}$, It means that income is not a major determinant of housing affordability.

The available data from the primary sources was used to analyze the effect of the various identified variables on the rental housing affordability. On the specific, the individual rental paid on current accommodation was used as the basis to analyze if the person is having an adequate accommodation in relation to income (salary), family size and other household needs. The multiple regression analysis was used to investigate the result of the hypotheses propounded. It was also used to answer some of the research questions. Tables and percentages were mostly employed to answer the research questions.

\section{Data Presentation and Analysis}

A total of two hundred and fifty questionnaires were distributed to workers in the five tertiary institutions under study, only one hundred and ninety one were returned. This represents a response rate of $76.4 \%$ which should be acclaimed a good rate. The highest response rate of $92 \%$ percent was recorded in Imo State Polytechnic while the least response rate was $66 \%$ at Imo State University. The respondents include both the academic and non-academic staff of these institutions. The non-academic staff forms the bulk of the respondents due to the area of concentration on the grade levels. More over majority of the junior and medium staff usually live in rented accommodations which is the basis of the research work (Table 1 ).

Table 2 shows that the average household size of the respondents is four. However, there is a high preponderance of household size of 5 and above (54.4\%) which will require the provision of more housing or there will be more pressure on existing housing which will result in higher rentals.

In response to workers' grade level, the respondents vary within the various grade levels. Out of 191 respondents, 30 representing 15\% were workers on grade level 01-03 and workers on grade level 04-06 were 66 representing 34.5\%.

Table 1. Distribution of questionnaires to various institutions.

\begin{tabular}{cccc}
\hline Institutions & $\begin{array}{c}\text { No. of } \\
\text { Questionnaires } \\
\text { Distributed }\end{array}$ & $\begin{array}{c}\text { No. of } \\
\text { Questionnaires } \\
\text { Returned }\end{array}$ & $\begin{array}{c}\text { Response } \\
\text { Rate }\end{array}$ \\
\hline Federal University of Technology (FUTO) & 50 & 39 & $78 \%$ \\
Imo State University (IMSU) & 50 & 33 & $66 \%$ \\
Imo State Polythechnic, Umuagwo & 50 & 46 & $92 \%$ \\
Federal Polytechnic Nekede. & 50 & 35 & $70 \%$ \\
AlvanIkoku Federal College of Education. & 50 & 38 & $76 \%$ \\
Total & 250 & 191 & $76.4 \%$ \\
\hline
\end{tabular}


Table 2. Respondent according to family size.

\begin{tabular}{cccccccc}
\hline \multirow{2}{*}{ Family Size } & \multicolumn{5}{c}{ Institutions } & Total & Percentage \\
\cline { 2 - 6 } & FUTO & IMSU & IMPOLY & FEDPOLY & AIFCE & & \\
\hline 1 & 1 & - & 2 & 3 & 1 & 7 & $3.7 \%$ \\
2 & 6 & 4 & 5 & 3 & 5 & 23 & $12.1 \%$ \\
3 & 8 & 3 & 9 & 4 & 6 & 30 & $15.7 \%$ \\
4 & 3 & 3 & 6 & 8 & 7 & 27 & $14.1 \%$ \\
5 & 7 & 15 & 13 & 10 & 9 & 54 & $28.3 \%$ \\
6 and Above & 14 & 8 & 11 & 7 & 10 & 50 & $26.1 \%$ \\
Total & 39 & 33 & 46 & 35 & 38 & 191 & $100 \%$ \\
Average & 4 & 5 & 4 & 4 & 4 & Overall Ave: 4 \\
\hline
\end{tabular}

95 respondents representing about $49.8 \%$ were workers on grade level 07-09. The grade levels of academic staff usually start from 06 for Technicians in the Polytechnics and 07 (an equivalent of 01 in the university) as Graduate Assistants (Table 3).

Group one is a government residential area which is designed for only detached and semi-detached duplex and few bungalows. The average annual rent passing for this type of accommodation varies between N350,000 - N380,000. Areas in Group B are all government designed layouts which are made up of detached and semi-detached bungalows. Group three has also majority of government layouts that are made up of both block of flats and detached bungalows. This type of accommodation is usually preferred and available. Group four consists of private layouts and sub-urban areas. Some of the areas in this group are found in the city center and are typified with older accommodation which explains why their rents and that of those in the sub-urban are the same. Last group is found within the rural setting which is still on the developing stage thus explaining the lower rates (Table 4).

Table 5 shows an annual average expenditure on food and drinks by the various categories of staff. The staff within grade level 01-03 spends an annual average of N262,000, those within grade level 04-06 spends N355,000 while the third category of being those on grade level 07-09 spends an average of $\mathrm{N} 486,000$. It is important to note that these expenditures are dependent on family size and age composition.

On the average, these categories of staff spend an annual amount on clothing as follows: Staff on GL 01-03 spends N66,000, Staff on GL 04-06 spends N77,000 while 07-09 spends N102,000 (Table 6).

The average annual expenditure on education for staff on grade level 01-03 is N66,000, that of staff on grade level 04-06 is N95,000 and N127,000 for staff on grade level 07-09. A critical view on this Table 7 reveals that no staff on level 07-09 spends less than N110,000 on education and none on level 04-06 spends less than N70,000 on education. Just a few of those in level 01-03 spends less than $\mathrm{N} 25,000$ on education. 
Table 3. Respondent according to Grade level and its equivalent.

\begin{tabular}{|c|c|c|c|c|c|c|c|}
\hline \multirow{2}{*}{$\begin{array}{c}\text { Grade } \\
\text { Level/Equivalent }\end{array}$} & \multicolumn{5}{|c|}{ Institution } & \multirow{2}{*}{ Total } & \multirow{2}{*}{ Percent } \\
\hline & FUTO & IMSU & IMPOLY & FEDPOLY & AIFCE & & \\
\hline 01-03 & 8 & 3 & 8 & 5 & 6 & 30 & $15.7 \%$ \\
\hline 04-06 & 16 & 12 & 15 & 12 & 11 & 66 & $34.5 \%$ \\
\hline 07-09 & 15 & 18 & 23 & 18 & 21 & 95 & $49.8 \%$ \\
\hline Total & 39 & 33 & 46 & 35 & 38 & 191 & $100 \%$ \\
\hline
\end{tabular}

Table 4. Showing the classification or grouping of area according to the average rents in Owerri.

\begin{tabular}{|c|c|c|c|c|c|c|c|}
\hline \multirow{2}{*}{ Group } & \multirow{2}{*}{ Area } & \multirow{2}{*}{ Type of Accommodation } & \multicolumn{5}{|c|}{ Average Rent Passing ( $\left({ }^{\prime} 000\right)$} \\
\hline & & & Single Room & One b/drm & Two b/drms & Three b/drms & Four b/drms \\
\hline One & $\begin{array}{l}\text { Egbeada Fed. Housing, } \\
\text { Works layout, Area G }\end{array}$ & $\begin{array}{l}\text { Detached/semi } \\
\text { detached duplex }\end{array}$ & & & & 350 & 380 \\
\hline Two & $\begin{array}{l}\text { Aladimma, Pre-Fab } \\
\text { Trans-Egbu }\end{array}$ & $\begin{array}{c}\text { Detached/semi-detached } \\
\text { bungalows }\end{array}$ & & & 220 & 300 & 320 \\
\hline Three & $\begin{array}{l}\text { Ikenegbu, Ikenegbu Est., } \\
\text { Area A, Mcc Road, } \\
\text { Okigwe Rd, World } \\
\text { Bank Estate, Umuguma } \\
\text { Fed Housg. Redemption } \\
\text { Estate, Uratta East } \\
\text { and West layout }\end{array}$ & $\begin{array}{c}\text { Block of flats, } \\
\text { detached, bungalow }\end{array}$ & & & 220 & 280 & 300 \\
\hline Four & $\begin{array}{c}\text { Amakohia, Akwuakuma, } \\
\text { Owerri Urban, Irete, } \\
\text { Orji, Nekede Old Rd, } \\
\text { Naze, Obinze, Nekede }\end{array}$ & $\begin{array}{c}\text { Tenement bldings, } \\
\text { Block of flats, Detached bungalow }\end{array}$ & 36 & 96 & 132 & 180 & \\
\hline Five & Avu, Mgirichi & Bungalow, block of flats & - & - & 102 & 120 & \\
\hline
\end{tabular}

Table 5. Showing average annual expenditure of staff on food and drink.

\begin{tabular}{|c|c|c|c|c|}
\hline \multirow{2}{*}{$\begin{array}{l}\text { Mid Points of Amt. } \\
\text { P.A ( } 000)\end{array}$} & \multirow{2}{*}{ Household Size } & \multicolumn{3}{|c|}{ No. of Respondents According to Grade Levels } \\
\hline & & 01-03 & 04-06 & 07-09 \\
\hline & $1-3$ & 3 & 2 & - \\
\hline \multirow[t]{3}{*}{100} & $4-5$ & - & - & - \\
\hline & 6 and above & - & - & - \\
\hline & $1-3$ & 16 & 22 & 11 \\
\hline \multirow[t]{3}{*}{280} & $4-5$ & 8 & 11 & 10 \\
\hline & 6 and above & 3 & 3 & - \\
\hline & $1-3$ & - & 1 & 5 \\
\hline \multirow[t]{3}{*}{480} & $4-5$ & - & 5 & 32 \\
\hline & 6 and above & - & 11 & 18 \\
\hline & $1-3$ & - & - & - \\
\hline \multirow[t]{2}{*}{730} & $4-5$ & - & - & 5 \\
\hline & 6 and above & - & - & 14 \\
\hline \multicolumn{2}{|c|}{ Average Expenditure } & 262,000 & 352,000 & 486,000 \\
\hline
\end{tabular}


Table 6. Average annual expenditure of staff on clothing.

\begin{tabular}{|c|c|c|c|c|}
\hline \multirow{2}{*}{$\begin{array}{l}\text { Mid Points of Amt. } \\
\text { P.A ( } 000)\end{array}$} & \multirow{2}{*}{ Household Size } & \multicolumn{3}{|c|}{ No. of Respondents According to Grade Levels } \\
\hline & & $01-03$ & 04-06 & 07-09 \\
\hline & $1-3$ & - & - & - \\
\hline \multirow[t]{3}{*}{15} & $4-5$ & - & - & - \\
\hline & 6 and above & - & - & - \\
\hline & $1-3$ & 15 & 23 & 4 \\
\hline \multirow[t]{3}{*}{55} & $4-5$ & 6 & 10 & 8 \\
\hline & 6 and above & 2 & 3 & 2 \\
\hline & $1-3$ & 4 & 2 & 11 \\
\hline \multirow[t]{3}{*}{100} & $4-5$ & 2 & 16 & 28 \\
\hline & 6 and above & 1 & 9 & 15 \\
\hline & $1-3$ & - & - & 1 \\
\hline \multirow[t]{2}{*}{135} & $4-5$ & - & - & 11 \\
\hline & 6 and above & & 3 & 15 \\
\hline \multicolumn{2}{|c|}{ Average Expenditure } & 66,000 & 77,000 & 102,000 \\
\hline
\end{tabular}

Table 7. Average annual expenditure of staff on education.

\begin{tabular}{|c|c|c|c|c|}
\hline \multirow{2}{*}{$\begin{array}{l}\text { Mid Points of Amt. } \\
\text { P.A ( }\left({ }^{\prime} 000\right)\end{array}$} & \multirow{2}{*}{ Household Size } & \multicolumn{3}{|c|}{ No. of Respondents According to Grade Levels } \\
\hline & & $01-03$ & $04-06$ & 07-09 \\
\hline & $1-3$ & 5 & - & - \\
\hline \multirow[t]{3}{*}{25} & $4-5$ & 1 & - & - \\
\hline & 6 and above & - & - & - \\
\hline & $1-3$ & 13 & 16 & - \\
\hline \multirow[t]{3}{*}{70} & $4-5$ & 7 & 12 & - \\
\hline & 6 and above & - & - & - \\
\hline & $1-3$ & 1 & 9 & 15 \\
\hline \multirow[t]{3}{*}{110} & $4-5$ & - & 14 & 26 \\
\hline & 6 and above & 3 & 12 & 9 \\
\hline & $1-3$ & - & - & 1 \\
\hline \multirow[t]{2}{*}{145} & $4-5$ & - & - & 21 \\
\hline & 6 and above & - & 3 & 23 \\
\hline \multicolumn{2}{|c|}{ Average Expenditure ( 000$)$} & 66,000 & 95,000 & 127,000 \\
\hline
\end{tabular}

Table 8 explains the extent of staff expenditure on the following variables It thus reveals that transportation expenses rates highest in the table thus a greater percentage of the staff spends so much on transportation while the least expenses is on health care. 
Table 8. Average Annual Expenditure on the following variables.

\begin{tabular}{|c|c|c|c|c|c|c|c|c|c|c|}
\hline \multirow{2}{*}{$\begin{array}{c}\text { Mid pt of Amt P.A } \\
(000)\end{array}$} & \multirow{2}{*}{ H/H Size } & \multicolumn{3}{|c|}{ Health/Medicare } & \multicolumn{3}{|c|}{ Social Activity } & \multicolumn{3}{|c|}{ Transport } \\
\hline & & 01-03 & $04-06$ & $07-10$ & 01-03 & 04-06 & $07-10$ & 01-03 & 04-06 & 07-09 \\
\hline \multirow{3}{*}{5} & $1-3$ & 2 & 1 & - & 1 & 1 & - & - & - & - \\
\hline & $4-5$ & 1 & - & - & - & - & - & - & - & - \\
\hline & 6 and above & - & - & - & - & - & - & - & - & - \\
\hline \multirow{3}{*}{20} & $1-3$ & 17 & 10 & 8 & 12 & 16 & 3 & 9 & 5 & - \\
\hline & $4-5$ & 7 & 5 & 3 & 5 & 4 & 1 & 3 & - & - \\
\hline & 6 and above & 2 & 3 & 2 & 2 & 3 & - & 1 & - & - \\
\hline \multirow{3}{*}{40} & $1-3$ & - & 14 & 6 & 6 & 8 & 13 & 10 & 21 & 12 \\
\hline & $4-5$ & - & 21 & 36 & 3 & 20 & 31 & 5 & 19 & 8 \\
\hline & 6 and above & 1 & 12 & 20 & 1 & 11 & 17 & 2 & 10 & 4 \\
\hline \multirow{3}{*}{70} & $1-3$ & - & - & 2 & - & - & - & - & - & 3 \\
\hline & $4-5$ & - & - & 8 & - & 2 & 15 & - & 6 & 40 \\
\hline & 6 and above & - & - & 10 & - & 1 & 15 & - & 5 & 28 \\
\hline \multicolumn{2}{|c|}{ Average Expenditure ( $\left.\mathbb{N}^{\prime} 000\right)$} & 19 & 34 & 44 & 26 & 34 & 49 & 31 & 44 & 62 \\
\hline
\end{tabular}

Staff on grade level 01-03 have an average annual expenditure of N470,000, staff on grade level 04-06 spends an average of N569,000 annually. The last category of 07-09 have an annual average expenditure of N870,000 (Table 9).

Table 10 depicts that about $61.3 \%$ representing more than half of the respondent travel quite a distance to their place of work. $14.1 \%$ of the respondents also live far, while $23 \%$ reside close to their work place. $1.6 \%$ of the respondents are relatively privileged to live within the staff quarters of the school.

Table 11 tries to show respondents reactions toward the rate of adequacy of their present accommodation. $41 \%$ of the respondents acclaimed that their place of residence is adequate, $18.8 \%$ says theirs is even so adequate and $28 \%$ of them there is manageable. Only $10.5 \%$ of the respondents say that their present accommodation is not adequate.

Table 12 relates the present rent they pay to their income, $61.8 \%$ acclaims that they are comfortable with the rent they pay while $38.2 \%$ of refute the assertion. Most of the income these individuals state is either additional to their salaries or total household income (both spouse).

A greater percentage of the respondents say that what informed the choice of their present accommodation is that of availability and affordability. $25 \%$ choose the accommodation to spend less on transportation irrespective of the nature of the accommodation and area. $8.4 \%$ says they preferred the neighborhood where they reside while $10.5 \%$ is more interested in the cost or affordability. At the same time $20 \%$, which is a large percentage rented the accommodation because of the availability (Table 13).

From Table 14 above, only few of the respondents pay as low as the stated 
Table 9. Overall expenditure on other household variables.

\begin{tabular}{cccc}
\hline \multirow{2}{*}{ Expenditure Variables } & \multicolumn{3}{c}{ Average Expenditure According to Grade Levels (000) } \\
\cline { 2 - 4 } & $01-03$ & $04-06$ & $07-09$ \\
\hline Food and Drinks & 262 & 352 & 486 \\
Clothing & 66 & 77 & 102 \\
Education & 66 & 95 & 127 \\
Health and Medicare & 19 & 34 & 44 \\
Social Activity & 26 & 34 & 49 \\
Transport & 31 & 44 & 62 \\
Total Average & 470 & 569 & 870 \\
\hline
\end{tabular}

Table 10. Showing response on distance from place of residence to work place.

\begin{tabular}{|c|c|c|c|c|c|c|c|}
\hline \multirow{2}{*}{ Reactions } & \multicolumn{5}{|c|}{ No. of Respondents } & \multirow{2}{*}{ Total } & \multirow{2}{*}{ Percentage } \\
\hline & FUTO & IMSU & IMPOLY & FEDPOLY & AIFCE & & \\
\hline Very Far & 8 & 3 & 20 & 13 & - & 44 & $23.1 \%$ \\
\hline Quite Far & 25 & 9 & 17 & 13 & 9 & 73 & $38.2 \%$ \\
\hline Far & 3 & 7 & 5 & - & 12 & 27 & $14.1 \%$ \\
\hline Close & 3 & 7 & - & 5 & 3 & 18 & $9.4 \%$ \\
\hline Very Close & - & 7 & 4 & 4 & 11 & 26 & $13.6 \%$ \\
\hline \multirow[t]{2}{*}{ Within } & - & - & - & - & 5 & 3 & $1.6 \%$ \\
\hline & 89 & 33 & 46 & 35 & 38 & 191 & $100 \%$ \\
\hline
\end{tabular}

Table 11. Showing rate of adequacy of staff present accommodation.

\begin{tabular}{|c|c|c|c|c|c|c|c|}
\hline \multirow{2}{*}{ Reactions } & \multicolumn{5}{|c|}{ No. of Respondents } & \multirow{2}{*}{ Total } & \multirow{2}{*}{ Percentage } \\
\hline & FUTO & IMSU & IMPOLY & FEDPOLY & AIFCE & & \\
\hline Very Poor & - & - & - & - & - & - & - \\
\hline Poor & 3 & 2 & 7 & 2 & 6 & 20 & $10.5 \%$ \\
\hline Fair & 11 & 10 & 18 & 8 & 8 & 55 & $28.8 \%$ \\
\hline Good & 16 & 13 & 19 & 17 & 15 & 80 & $41.9 \%$ \\
\hline Very Good & 9 & 8 & 2 & 8 & 9 & 36 & $18.8 \%$ \\
\hline \multirow[t]{2}{*}{ Excellent } & - & - & - & - & - & - & - \\
\hline & 89 & 33 & 46 & 35 & 38 & 191 & 100 \\
\hline
\end{tabular}

Table 12. Showing rent affordability in relation to income.

\begin{tabular}{cccccccc}
\hline \multirow{2}{*}{ Response } & \multicolumn{5}{c}{ No. of Respondent } & \multirow{2}{*}{ Total } & Percentage \\
\cline { 2 - 6 } & FUTO & IMSU & IMPOLY & FEDPOLY & AIFCE & & \\
\hline Yes & 26 & 22 & 18 & 25 & 27 & 118 & $61.8 \%$ \\
No & 13 & 11 & 28 & 10 & 11 & 73 & $38.2 \%$ \\
\hline
\end{tabular}


Table 13. Showing choice of accommodation.

\begin{tabular}{|c|c|c|c|c|c|c|c|}
\hline \multirow{2}{*}{ Reactions } & \multicolumn{5}{|c|}{ No. of Respondents } & \multirow{2}{*}{ Total } & \multirow{2}{*}{ Percentage } \\
\hline & FUTO & IMSU & IMPOLY & FEDPOLY & AIFCE & & \\
\hline Availability Only & 6 & 6 & 11 & 6 & 10 & 39 & $20.4 \%$ \\
\hline Availability/Affordability & 18 & 11 & 21 & 8 & 9 & 67 & $35 \%$ \\
\hline Affordability Only & 6 & 4 & 3 & 7 & - & 20 & $10.5 \%$ \\
\hline Nearness to Work Place & 3 & 11 & 9 & 9 & 17 & 49 & $25.7 \%$ \\
\hline \multirow[t]{2}{*}{ Neighborhood Characteristics } & 6 & 1 & 2 & 5 & 2 & 16 & $8.4 \%$ \\
\hline & 39 & 33 & 46 & 35 & 38 & 191 & $100 \%$ \\
\hline
\end{tabular}

Table 14. Showing average salary in relation to rent subsidy.

\begin{tabular}{ccccc}
\hline Grade Levels & Average Net Salary & $\begin{array}{c}\text { Least Rent Paid on } \\
\text { Present Accommodation }\end{array}$ & $\begin{array}{c}\text { Rent } \\
\text { Subsidy }\end{array}$ & $\begin{array}{c}\text { Make up } \\
\text { for Rent }\end{array}$ \\
\hline 01 & 309,333 & 74,000 & 46,508 & 27,492 \\
02 & 322,851 & 80,000 & 48,889 & 31,111 \\
03 & 348,044 & 84,000 & 52,816 & 31,184 \\
04 & 397,099 & 88,000 & 60,461 & 27,539 \\
05 & 484,990 & 96,000 & 74,166 & 21,834 \\
06 & 770,426 & 100,000 & 117,180 & No make \\
07 & $1,164,942$ & 150,000 & 149,724 & "' \\
08 & $1,357,724$ & 180,000 & 176,837 & " \\
09 & $1,557,058$ & 180,000 & 205,466 & \\
\hline
\end{tabular}

(Source: Bursary Department of the Tertiary Institutions).

and the type of accommodation that command the rent are can only fit for a very small family size. Quite a negligible number of the respondents fall in this category.

\section{The Regression Analysis Result}

These are the relevant computer print-out of the regression analysis based on the Statistical Package for Social Sciences (SPSS):

R squared $\left(R^{2}\right)=0.41$ or $41 \%$.

Coefficients:

$$
\begin{aligned}
& a=75.527, b_{1}=5.037 \mathrm{E}-02=0.05037 \\
& b_{2}=8.578, b_{3}=1.254 \mathrm{E}-02=0.01254 ; \\
& f_{c a l} \text { (from ANOVA) }=43.377, f_{\text {tab }}=1.20 ; \\
& t_{c a l} \text { for } x_{1}=6.628, t_{c a l} \text { for } x_{2}=2.802, t_{c a l} \text { for } x_{3}=0.570 ; \\
& t_{\text {tab }}=1.96 \text { same as } Z_{\text {table }}(=1.96 @ 0.05 \text { level of significance) for sample }>30 .
\end{aligned}
$$

\section{Interpretation of Results}

1) Estimated Regression Equation

There is a common belief that one's decision on the type of accommodation vis a vis the rent payable or affordable is dependent on series of variables. Some 
of these variables are income, other household expenditure, family size, status in the society, neighbourhood characteristics, and nearness to workplace among many others. This research work tried to establish that among these variables, there are some that are more significant in determining ones rental housing affordability potential. It went further to develop an estimated equation which one can use to predict or forecasts a person's rental housing affordability potentials. The estimated equation is presented as thus:

$$
Y=a+b_{1} x_{1}+b_{2} x_{2}+b_{3} x_{3} e
$$

$Y=$ Affordable rent (Dependent Variable);

$x_{1}=$ Income;

$X_{2}=$ Household size;

$x_{3}=$ other household expenditure;

$b=$ coefficient of regression;

$y=75.527+(0.05037$ income $)+(8.578$ family size $)+(0.01254$ other household expenditure).

2) The R Squared $\left(R^{2}\right)$

The $\mathrm{R}^{2}$ statistically measures how well the model fits the data. The regression analysis shows that the $\mathrm{R}^{2}$ is. 410 or $41 \%$ which represents an average of the total variables the affect rental affordability. It also explains that there are other variables that affect ones rental affordability.

3) Result on Strength of Combined Variables

The result of the combined strength of the three variables (income, household size and other household expenditures) shows that the $f_{\text {cal }}$ (from ANOVA) is 43.377 while the $f_{\text {tab }}$ is 1.20 .

The theory states that if $f_{c a l}>f_{t a b}$, it shows that the variables are significant ie the variables are very important in determining ones rental housing affordability potentials. On the contrary, if $f_{c a l}<f_{\text {tab }}$ the reverse will be the case.

Since in this situation, $f_{c a l}>f_{t a b}$, it then means that the variables are very important.

4) Test on Individual Variable

Testing whether a variable is important in explaining the rental housing affordability while others remain constant, the theory here also stipulates that $t$ stands for smaller samples but if the sample is greater than 30 then $t_{t a b}$ will be 1.96. As the result stands $t_{c a l}$ for $x_{1}=6.628, t_{c a l}$ for $x_{2}=2.802, t_{c a l}$ for $x_{3}=0.570 . t_{c a l}$ for both $x_{1}$ and $x_{2}$ are quite significant since they are greater than the $t_{t a b}$. This invariably explains that income and family size are very important in determining rental housing affordability potentials while other expenditure is not very significant.

\section{Discussion}

Rent varies on type of accommodation and neighbourhood or layout being situated. The areas in group one and group two are characterized with serene en- 
vironment with a classified type of accommodation. The type of accommodation and environment in these areas account for the high rent the properties command. It was also obvious that three bedroom flats are more available than the other type of accommodation, whereas the two and one bedroom which would have been suitable for a smaller family at a lower rent is usually scarce.

Accommodations within the city centre are expected to command higher rent than those in the sub-urban but their rental values are virtually the same. It was observed that most properties in the city centre are old fashioned and lack proper maintenance whereas there are more modern structures within the sub-urban. People tend to prefer the modern buildings in the sub-urban irrespective of poor condition of the roads, to avoid the hustle and bustle associated with the city centre.

Majority of the staff reside very far from their places of work, especially the schools that are far away from the city. The inability of proper developments around these schools forced the staff to travel quite a distance to their work places. The cost of transportation and its other attendant problems virtually contribute to the increase in workers transportation expenses. This expense can either be on the cost of transportation and the cost of maintenance on the vehicle due to wear and tear.

Survey reveals that a greater number of the respondents live in an accommodation they feel that is adequate. The question is whether the adequacy of the accommodation is relative to their salary irrespective of other sources of income. On the contrary majority of the staff in the lower category have annual expenditure housing inclusive that is far above their salaries.

Rent subsidy for the lower category of staff is not really enough when compared to their present accommodation. The stipulated subsidy could limit them to a smaller accommodation which in most cases not adequate for majority of the family size.

The research revealed that one's decision on the type of accommodation to go for is dependent on a lot of variables such as income, family size, expenditure on other household needs, status, neighbourhood, etc. The hypotheses also show that income and family size are significant in determining someone's ability to rant adequate accommodation.

\section{Conclusion}

Expenditure on other household needs such as food/drinks, clothing, Education, Health/Medicare, Social activities and transportation are all dependent on income, family size, preference and Status (as a component of grade level). Hence staff on the same grade level might not have the same household expenditure unless they have other things in common. The research has been able to consolidate the generally accepted fact that housing is a very fundamental issue for human existence. It has always been a known fact that man's comfort is ensured if he has the ability of having adequate and affordable home. This explains why 
people travel a long distance to their work place in search of better accommodation and environment that will guarantee a healthy living.

The research questions and hypotheses postulated in the study were adequately attended to. The answer to research question three was on the affirmative showing that worker's adequate residential housing affordability can be ascertained. The regression analysis was also able to establish the relationship that exists between adequate housing affordability vis-à-vis the rent and variables such as income, family size and other expenditure.

Consequent to this, an estimated equation for ascertaining the ability of staff in affording adequate housing was also established using the multiple regression techniques. This can nevertheless be reliable way to administratively describe housing expenditures of households and to analyze trends, define eligibility criteria and subsidy levels for public housing purposes. It can as well be a valid instrument for Estate Surveyors in tenant selection or rent setting.

\section{Recommendations}

Sequel to the findings made in this study, the following recommendations would be made:

1) The study revealed that majority of the staff within the lower income group cannot afford adequate housing without any form of assistance. The institutions in collaboration with the Government should embark on programmes to provide staff housing inform of social housing. This project should be specifically for a certain group of workers and should be close to the institution if not within to reduce transportation cost on the workers.

2) A staff housing scheme should also be encouraged within the institutions especially the institutions that are far from the city centre. The housing should be in form of a neighbourhood that will attract other economic and social activities for the inhabitants.

3) To reduce the rental value of properties, government should implement these laid down housing programme. While implementing this program, various income groups should be put into consideration. Allocations should also be made in such a way that the lower-income group is incorporated.

4) Mass transit system should also be encouraged especially for the institutions that are far from the town. Management of these institutions should work on the proposed mass transit initiatives of the government to ensure that their institution benefits from it. A good transportation system will go a long way in reducing expenses incurred by staff.

\section{Limitation of Research and Suggestions for Further Research}

The study revealed that there are many variables that influence ones' rental housing affordability and choice of accommodation. The variables used in this study represent $41 \%$ of the total variables that affect housing affordability, while 
the other $59 \%$ is still untapped. The three variables used have ease of information and are quantifiable; we suggest that in-depth should be made on the remaining variables. Further studies should also be extended to staff of other public offices and institutions in other Nigerian cities, also to other facets of housing such as adequate housing for owner-occupier (either for construction or outright purchase).

\section{Conflicts of Interest}

The authors declare no conflicts of interest regarding the publication of this paper.

\section{References}

Asogwa, I. (2010). Rising Cost of Building Materials, Threat to Adequate Housing. http://allafrica.com/stories/201010280329.html

Bogdon, A. S., \& Can, A. (1997). Indicators of Local Housing Affordability: Comparative and Spatial Approaches. Real Estate Economics, 25, 43-80. https://doi.org/10.1111/1540-6229.00707

Bramley, G. (1990). Access, Affordability and Housing Need. A Paper Presented to the School for Advanced Urban Studies, Bristol: University of Bristol.

Byron, S. (2002). Affordable Housing Strategy for Urban Areas 2002. http://www.Byron.nsw.gov.au

Feins, J. D., \& Lane, T. S. (1981). How Much for Housing? New Perspectives on Affordability and Risk. Abt Books.

Freeman, A., \& Whitehead, C. (1995). Affordability Revisited in English Housing Association Assured New Let Accommodation. West Yorkshire: Halifax Building Society.

Freeman, A., Chaplin, R., \& Whitehead, C. (1997). Rental Affordability: A Review of International Literature. Discussion Paper 88, Cambridge: Property Research Unit, Department of Land Economy, University of Cambridge.

Gabriel, M., Jacobs, K., Arthurson, K., Burke, T., \& Yates, J. (2005). Conceptualizing and Measuring the Housing Affordability Problem National Research Venture 3: Housing Affordability for Lower Income Australians. Research Paper 1, Melbourne: Australian Housing and Urban Research Institute.

Kolawole, Y. (2010). Housing Development Not Sustainable on Household Income. Vanguard Newspapers. http://www.vanguardngr.com/2010/12

Marjorie, E. J. (1998). Affordability Indicators. In W. V. Vliet (Ed.), The Encyclopedia of Housing. Thousand Oaks, CA: Sage Publications.

Ndubueze, J. O. (2009). Urban Housing Affordability and Housing Policy Dilemmas in Nigeria. PhD Thesis, Birmingham: The University of Birmingham.

Nubi, T. O. (2008). Housing Finance in Nigeria-Need for Re-Engineering. Journal of Department of Estate Management University of Lagos.

Olayinwola, Adeleye, \& Ogunshakin (2005). Public Housing Delivery in Nigeria: Problems and Challenges. http://www.pdfcari.com

Omoniyi, M. I. (1994). A Critical Analysis of Housing Crisis in Nigeria. The Builders' Magazine, Vol. 11, No. 2, April/May 1994.

Onyike, J. O. (2007). An Assessment of Affordability of Housing by Public Servants in 
Owerri, Imo State. Land Use and Development Studies, January.

Onyike, J. O. (2009). The Urban Housing Problems of Nigeria in the 21st Century (p. 35). A Paper Presented at the Annual Conference of the Nigerian Institution Estate Surveyors and Valuers at Emmaus House, Awka Anambra State.

Quigley, J., \& Raphael, S. (2004). Is Housing Unaffordable? Why Isn't It More Affordable? Journal of Economic Perspectives, 18, 191-214.

https://doi.org/10.1257/089533004773563494

Stone, M. E. (1993). Shelter Poverty: New Ideas on Housing Affordability. Philadelphia, PA: Temple University Press.

Yates, J., Milligan, V., Berry, M., Burke, T., Gabriel, M., Phibbs, P., Pinnegar, S., \& Randolph, B. (2007). Housing Affordability: A 21st Century Problem (AHURI Final Report No. 105). Sydney: Australian Housing and Urban Research Institute Sydney Research Centre. 